UDC 004.942:629.023

V. Tigarev, DSc, Assoc. Prof., V. Salii,

A. Lopakov,

A. Goncharenko

Odessa National Polytechnic University, 1 Shevchenko Ave., Odessa, Ukraine, 65044; e-mail: volodymyr_t@ukr.net

\title{
DESIGN OF ENGINEERING OBJECTS USING THE INFORMATION MODEL
}

\begin{abstract}
B.M. Тігарєв, В.І. Салій, О.С. Лопаков, А.О. Гончаренко. Проектування інженерних об'єктів з використанням інформаційної моделі. Інформаційне проектування інженерних об'єктів базується на використанні інформаційних моделей об'єктів. Інформаційна модель дозволяє створити алгоритм проектування та виготовлення необхідного об̆'єкта. Дослідження спрямоване на розробку інформаційної моделі, яка дозволяє скоротити витрати часу на проектування, випробування та аналіз конструкції на навантаження. Нами запропоновано методику та технологію створення інформаційної комп'ютерної моделі рами електричного скутера. Детально розглянуто п'ять етапів конструкції рами з використанням інформаційної моделі. Докладно наведено послідовність проектування рами 3 двовимірного параметричного ескізу до тривимірної параметричної адаптивної моделі. У статті аналізується напруга та оптимізується конструкція рами електричного скутера 3 використанням програмного забезпечення для моделювання та проектування Autodesk Inventor, завдяки моделюванню з автоматизованим проектуванням (CAE) рами електричного скутера, аналізу напружень, чисельного аналізу та оптимізації каркасної конструкції. Досліджено вплив механічних навантажень на багажну частину та центральні елементи рами. Проведено аналіз симуляції, що дозволяє дослідити конструкцію на деформацію багажної частини та деформацію каркаса в цілому з урахуванням всіх навантажень. Здобуто відповідні оптимальні рішення для отримання надійної й безпечної конструкції рами електричного скутера. Результати симуляції навантаження дозволяють оптимізувати раму електричного скутера для різних варіантів конструкції. Запропонована інформаційна модель може бути використана для різних каркасних конструкцій. Використання інформаційної моделі скорочує час та підвищує надійність конструкції об'єкта. На основі отриманої інформаційної моделі буде розроблено в САПР Inventor підпрограму для автоматизованого проектування каркасних конструкцій електричних скутерів.

Ключові слова: інформаційна модель, рама електричного скутера, ескіз, моделювання, параметрична тривимірна модель

V. Tigarev, V. Saliy, A. Lopakov, A. Goncharenko. Designing of engineering objects using the information model. Information design of engineering objects is based on using the information models of objects. The information model allows you to create an algorithm for designing and manufacturing the desired object. The study aims to develop an information model that reduces the time spent on designing, testing, and analyzing load design. We propose a technique and technology for creating an information computer model of the frame of an electric scooter. Five stages of frame construction using the information model are discussed in detail. The sequence of designing a frame from a two-dimensional parametric sketch to a three-dimensional parametric adaptive model is described in detail. The article analyzes the voltage and optimizes the construction of the electric scooter frame using the Autodesk Inventor software for modeling and design, thanks to the automated design (CAE) simulation of the electric scooter frame, stress analysis, numerical analysis, and frame structure optimization. The influence of mechanical loads on the luggage part and the central elements of the frame are investigated. The simulation analysis is carried out, which allow to study the design for the deformation of the luggage part and the deformation of the frame as a whole, taking into account all the loads. Appropriate solutions have been obtained to obtain a reliable and secure frame construction for an electric scooter. The results of the load simulation allow you to optimize the frame of the electric scooter for different design options. The proposed information model can be used for different frame structures. Using an information model reduces time and increases the reliability of the object's construction. Based on the information model obtained, a subroutine for automated design of frame structures of electric scooters will be developed in CAD Inventor.

Keywords: information model, electric scooter frame, sketch, simulation, parametric three-dimensional model
\end{abstract}

\section{Introduction}

In recent years, the overuse of petroleum products for energy, modern industry and transport has contributed to the emission of exhaust gases such as carbon dioxide, causing global warming and leading to environmental disasters. Therefore, the forces of modern scientists should be directed to the development of new technologies to solve environmental problems arising from the use of old technologies. Thus, the use of alternative energy has become a development goal for many countries. In the modern world there is a great popularity of electric transport, in particular electric scooters [1, 2].

Modern engineering technology in computer-aided engineering requires the creation of an information model of the object being created. The information model should contain the methodology and

DOI: 10.15276/opu.2.58.2019.10

(c) 2019 The Authors. This is an open access article under the CC BY license (http://creativecommons.org/licenses/by/4.0/). 
technology of object creation [3, 4]. We have developed an information model for the frame of an electric scooter. This model will allow us to develop a common algorithm for designing objects of similar construction. This will shorten the design time and increase the reliability of the design.

The chassis of the electric scooter is designed to add two wheels to the bending and torsionresistant design, is one that will neither bend nor twist. It must be able to support all components and passengers and withstand all the loads required for this purpose without undue deviations. The chassis is a means of achieving this goal [5].

\section{Literature review and problem statement}

Recently, many scientific publications have been devoted to the practical use and theoretical study of information modeling in the life cycle of an object. The studies are aimed at developing an information model of the object, but they do not have sufficiently accurate analytical solutions to the problems of reducing the time spent on designing, testing and analyzing the design for loading. The literature provides solutions for the implementation of various models of the car frame [6 - 8], as well as a considerable amount of work is devoted to the design of the scooter frame [9-10] which were used to create a computer model of the frame of an electric scooter. This task is more conveniently accomplished with the Autodesk Inventor Professional CAD software, which allows you to create a parametric threedimensional model of the space frame of an electric scooter in the "Design frames" section. Parameterization allows you to analyze the created model for different profiles of structural elements.

\section{The purpose and tasks of the work}

In this regard, the purpose of the article is to make practical use of the information model capabilities in the process of designing an engineering object to reduce time costs, improve accuracy and create a computer model for the analysis of mechanical loads.

\section{Research materials and methods}

The information model of the electric scooter frame consists of several levels:

1. The level of linear objects. Creating a frame-vector-parametric sketch of a frame. It is created using the simplest frame elements. The frame is vector, because the direction of creation of the frame elements will be used in their modeling and profiling. The framework is parametric because all dimensions are linked and placed in the model parameter table.

2. The level of the three-dimensional model. Creating a model of a three-dimensional framework.

3 . The level of analysis of loads on the frame. Carrying out a study of the model of the loaded frame.

4. Optimization of the created model based on the results of load studies for compliance with the required parameters

5. Creation of design documentation for the manufacture of the frame of the electric scooter

In Fig. 1 is a block diagram of an information model that covers all the necessary levels and the relationships between them.

Consider in detail the frame of the electric scooter based on the proposed information model. We will design the frame using Autodesk Inventor software. Testing loads on frame model elements is performed in the Frame Analysis environment.

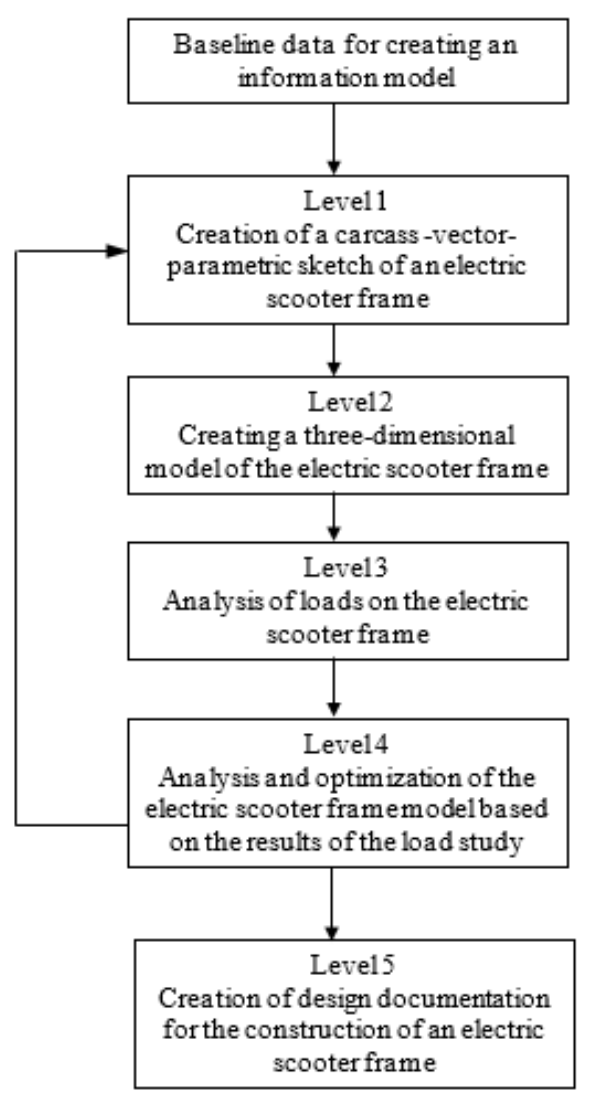

Fig. 1. Flowchart of the information model 
Adhering to all levels of the flowchart, we create a parametric three-dimensional model of the spatial frame of an electric scooter.

\section{Research results}

In the first stage of the study, a three-dimensional frame-vector model of the frame was developed, which is created using sketches of the frame framework model, sketches of the transverse frame members and stiffening ribs. Already in two-dimensional space, we create sketchy drawings, defining the necessary parametric dependencies. The sketches created to indicate the elements of the lower horizontal part of the frame are presented in Fig. 2, and sketches for the transverse elements in Fig. 3. A full three-dimensional sketch of the frame model is performed in 3D-sketch mode using 3D binding of all objects (Fig. 4).

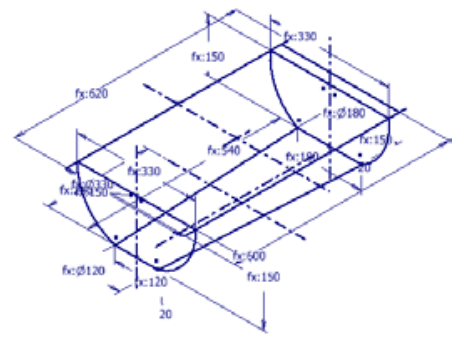

Fig. 2. Sketch of the base of the frame

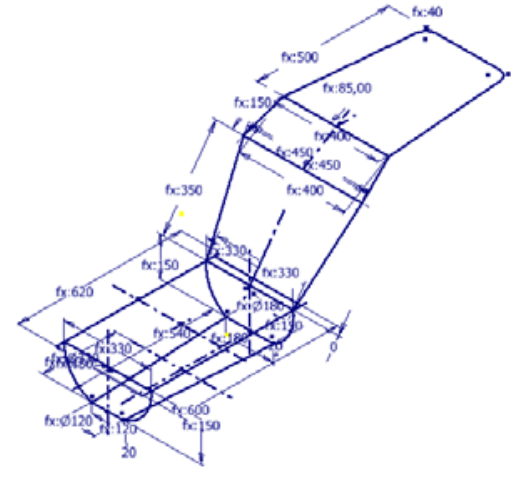

Fig. 3. Sketches of transverse elements

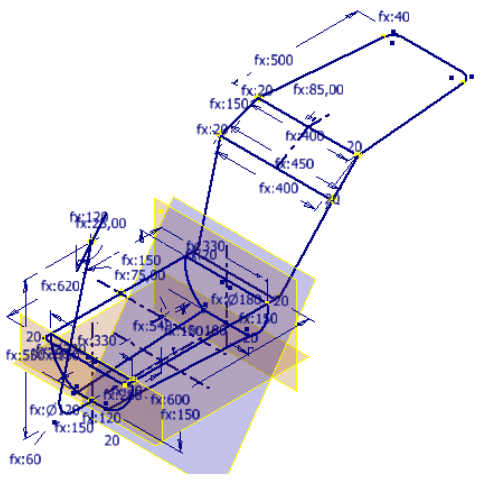

Fig. 4. Full 3D sketch of the frame

In the second stage, we perform profiling of the base and transverse frame members and profiling the stiffeners. To do this, we insert a created three-dimensional sketch into the build file and configure the standard profile type, define the material, as well as the anchor points of the profile. When all settings are complete, we get three-dimensional tubular elements ready to be installed in the main build file. Connection of components into a parametric three-dimensional model of the spatial framework is performed using the built-in module ILogic, using which we set the parameters and rules for changing them (Fig. 5) [11].

The computer model of the electric scooter frame is presented in Fig. 6 [9].

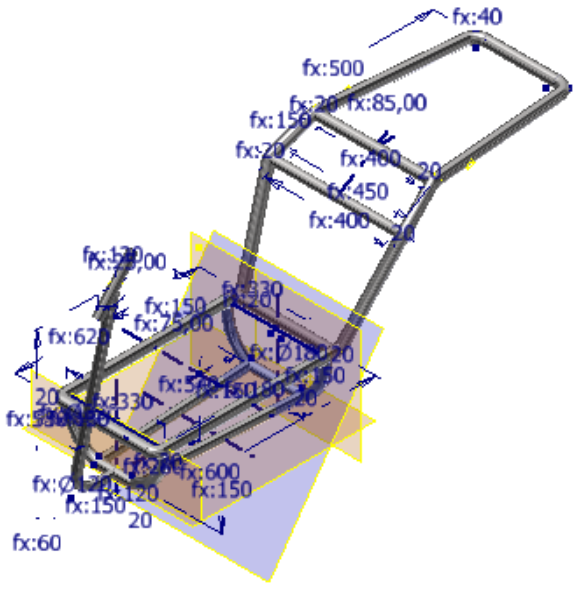

Fig. 5. Three-dimensional parametric model wit parameters

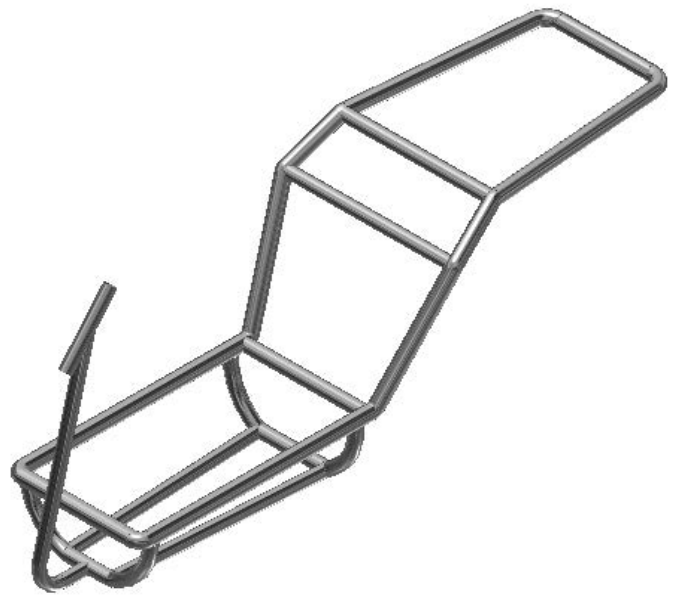

Fig. 6. Computer model of scooter frame 
The third stage will be the analysis of loads on the frame. We carry out studies on the load of the frame model (Fig. 7, Fig. 8). To do this, we use the frame analysis environment, in which we specify the direction and size of the applied force, as well as the place of fixation of the frame. We check the distribution of force across the sections of the frame, their response to the effect of force and load on the nodes.

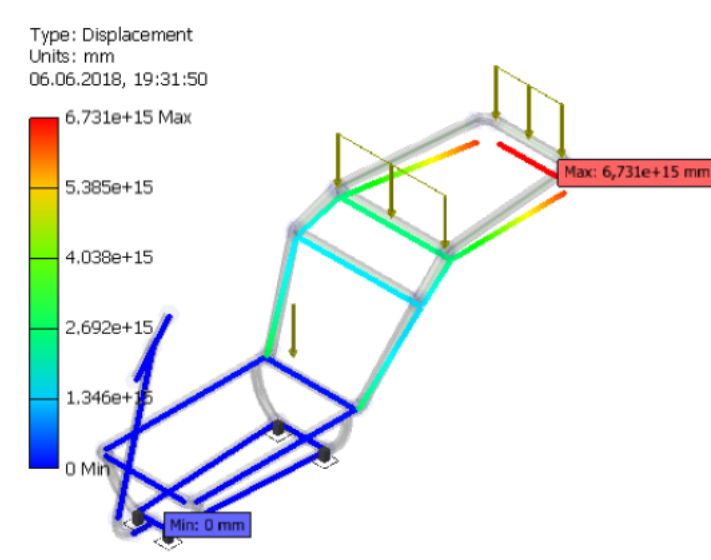

Fig. 7. Adjusting the load on the luggage compartment

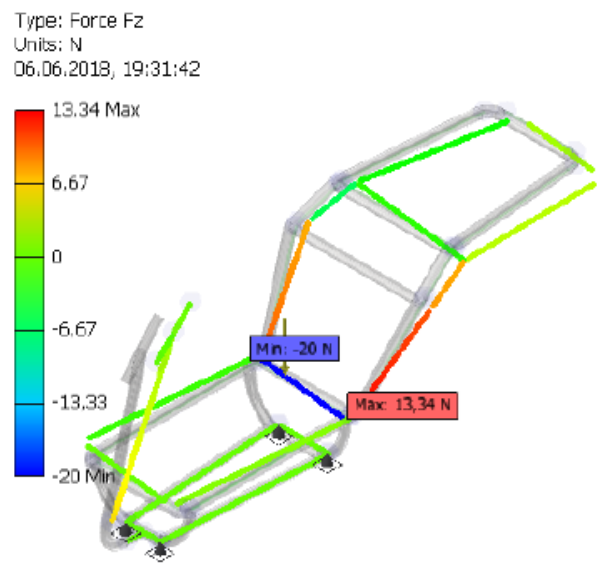

Fig. 8. Adding loads to the center of the frame

At the fourth level of the information model, we analyze the results of deformation of the frame (Fig. 9, Fig. 10). As a result of the simulation, increased loads on some nodes and deformation of the structure exceeding the allowable levels of shape deflection were found. To eliminate the disadvantages, it is necessary to add additional stiffeners to the structure to support unstable elements [2, 12].

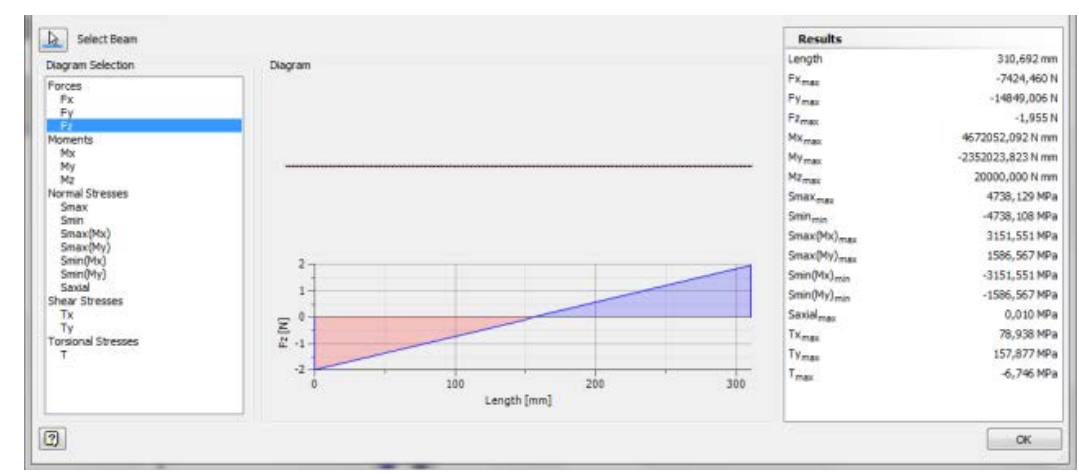

Fig. 9. The scheme of deformation of a frame on loading of a luggage part

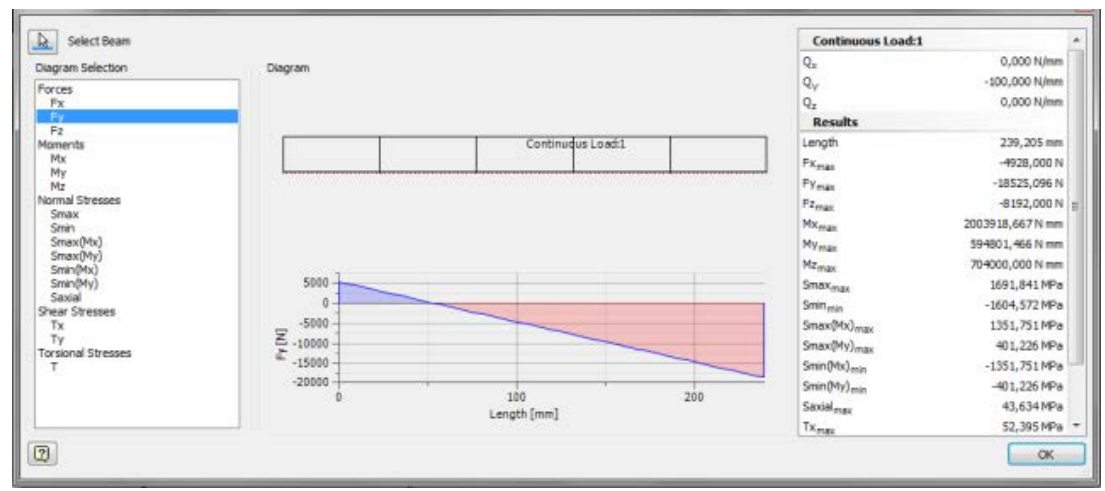

Fig. 10. The scheme of deformation of a frame taking into account all loadings 
Therefore, we optimize the design of the created model of the frame of the electric scooter based on the results of the study of loads for compliance with the required parameters. The final shape of the parametric model of the electric scooter frame is presented in Fig. 11 [10]. The fifth level of the information model is the creation of design documentation for the transmission of the model of the frame of the electric scooter.

\section{Discussion of results}

Our informational model allows us to create a computer model for further research and to create a simulation model. Using the created information model, the five stages of designing an electric scooter are considered in detail, resulting in a threedimensional parametric model. After analyzing the results of the load distribution simulation on the frame, unacceptable deformations were detected,

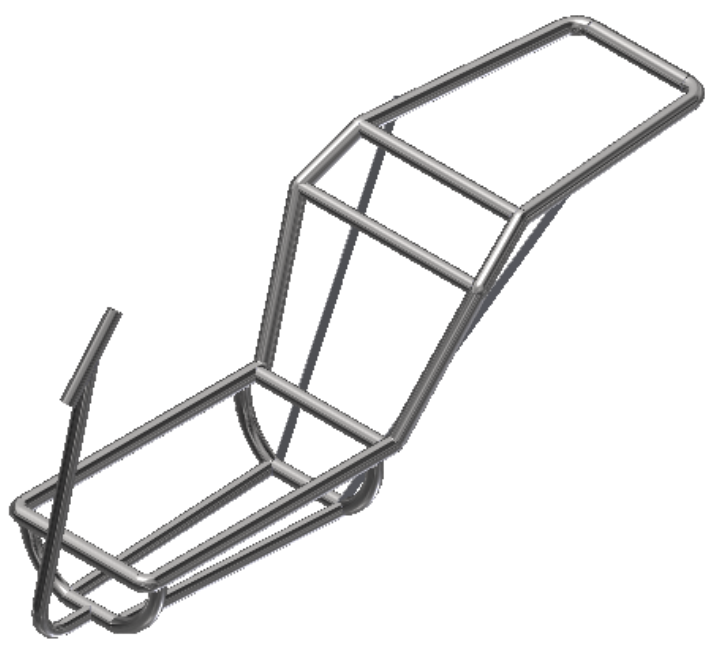

Fig. 11. Ready-made parametric model of an electric scooter frame which were eliminated by additional stiffeners.

\section{Conclusion}

The article deals with the general approach to the creation and analysis of the information model of the structure of the frame of an electric scooter. The block diagram of creation of three-dimensional model of frame-vector frame is considered. The technology of creating a three-dimensional parametric frame-vector model of the frame of an electric scooter in Autodesk Inventor Professional CAD is described in detail. Parametric 2D and 3D sketches were used to create the model. Using the created computer model, the frame model was tested in the Frame Analysis environment using the finite element method for static loads. The created information model of the electric scooter frame made it possible to shorten the prototype design time. Further development of the work is the development and creation of a computer program based on the proposed methodology for selecting the optimal version of the frame of the electric scooter for different designs. This can be accomplished with CAD Autodesk Inventor Professional in iLogic.

\section{Література}

1. Chien-Cheng Lin, Song-Jeng Huang, Chi-Chia Liu. Structural analysis and optimization of bicycle frame designs. SAGE journals. 2017. URL: https://journals.sagepub.com/doi/10.1177/ 1687814017739513.

2. Hsia Shao, Chou Yu-Tuan. Analysis of Welding Fatigue on Electric Scooter Using CAE Approach. Applied Mechanics and Materials. 2013. Vols. 291-294. P. 920-924. URL: www.scientific. net/AMM.291-294.920.

3. Wagner G. Information and Process Modeling for Simulation. Journal of Simulation Engineering. 2018. Volume 1, №1. P. 1-25. URL: https://jsime.org/index.php/jsimeng/article/view/2.

4. Анатолій Левенчук. Как описывать информационные модели крупных инженерных объектов. Живий журнал. 2011. URL: https://ailev.livejournal.com/962773.html.

5. Пронин В.А., Циганков А.В., Шляховецкий Д.В.Основи проектування каркасних конструкцій: Методичні вказівки для студентів усіх спеціальностей всіх форм навчання. СПб.: СПбГУНИПТ, 2012. 42 с.

6. Тонконогий В.М., Тігарєв В.М., Козирєва К.В. Розробка параметричної тривимірної моделі просторової рами автомобіля. Сучасні технології в машинобудуванні. 2014. № 28. С. 216-228.

7. Руснак С.В., Хамрай В.В., Новак М.О. Комп’ютерне моделювання і розрахунок рами спортивного автомобіля. Праці Одеського політехнічного університету. 2012. Вип. 2(39). С. 101-103.

8. Sood A., Singh P. Analysis of Space Frame of Formula SAEat High Speed with Ergonomic and Vibrational Factors. International Journal ofMechanicalEngineering and Technology. 2015. № 6(11). P. 202-212. URL: https://www.researchgate.net/publication/286921303_ANALYSIS_OF_SPACE _FRAME_OF_FORMULA_SAE_AT_HIGH_SPEED_WITH_ERGONOMIC_AND_VIBRATIONAL _FACTORS. 
9. Тигарев В.М., Тонконогий В.М., Гончаренко А.А. Общий подход к проектированию параметрической модели конструкции рамы электроскутера и симуляция нагрузок в САПР Inventor. Buсокi технології в машинобудуванні. 2018. Вип. 1(28). С. 139-149.

10. Тігарєв В.М., Гончаренко А.О. Створення підсистеми проектування та аналізу навантажень рами електроскуттера в сучасних САПР. Інформатика та математичні методи в моделювання. 2018. Т. 8, №3. C. 265-272.

11. Берналь М. Від параметричного до метамоделювання в дизайні. XX з'їзд Ібероамериканського товариства цифрової графіки : Збірники проектів Блюхера. 2016. Том. 3, № 1. С. 579-583.

12. Пуріч Д.А., Савельева О.С., Тонконогий В.М. Експрес-аналіз структурної надійності складних технічних систем з навантаженим резервуванням. Сучасні технології в машинобудуванні. 2013. № 8. C. 272-280.

\section{References}

1. Chien-Cheng Lin, Song-Jeng Huang, \& Chi-Chia Liu. (2017). Structural analysis and optimization of bicycle frame designs. SAGE journals. Retrieved from: https://journals.sagepub.com/doi/10.1177/ 1687814017739513.

2. Hsia, Shao, Chou, Yu-Tuan. (2013). Analysis of Welding Fatigue on Electric Scooter Using CAE Approach. Applied Mechanics and Materials, 291-294, 920-924. Retrieved from: www.scientific.net/ AMM.291-294.920.

3. Wagner, G. (2018). Information and Process Modeling for Simulation. Journal of Simulation Engineering,1, 1, 1-25. Retrieved from: https://jsime.org/index.php/jsimeng/article/view/2.

4. Anatoly, Levenchuk. (2011). How to describe information models of large engineering objects. Livejournal. Retrieved from: https://ailev.livejournal.com/962773.html.

5. Pronin, V.A., Tsygankov, A.V., \& Shlyahovetsky, D.V. (2012). Fundamentals of the design of frame structures : Methodical instructions for students of all specialties of all forms of training. SPb.: SPbGUNIPT.

6. Tonkonoghii, V.M., Tigarev, V.M., \& Kozyreva, K.V. (2014). Development of parametric threedimensional model of spatial frame of a car. Modern technology in mechanical engineering, 28. 216-228.

7. Rusnak, S.V., Khamray, V.V., \& Novak, M.A. (2012). Computer simulation and calculation of a sporting car frame. Proceedings of Odessa Polytechnic University, 2(39), 101-103.

8. Sood, A., \& Singh, P. (2015). Analysis of Space Frame of Formula SAEat High Speed with Ergonomic and Vibrational Factors. International Journal of Mechanical Engineering and Technology, 6(11), 202212. Retrieved from: https://www.researchgate.net/publication/286921303_ANALYSIS_OF_SPACE _FRAME_OF_FORMULA_SAE_AT_HIGH_SPEED_WITH_ERGONOMIC_AND_VIBRATIONAL FACTORS

9. Tigarev, V.M., Tonkonoghii, V.M., \& Goncharenko, A.O. (2018). General approach to the design of the parametric model of the frame construction of an electric scooter and the simulation of loads in the Inventor CAD system. High technology in mechanical engineering, 9, 139-149.

10. Tigarev, V.M., \& Goncharenko, A.O. (2018). Creation of subsystem for designing and analyzing loads of the electric scooter frame in modern carde. Informatics and Mathematical methods in simulation, 8, 3, 265-272.

11. Bernal, M. (2016). From Parametric to Meta Modeling in Design. XX Congreso de la Sociedad Iberoamericana de Gráfica Digital: Blucher Design Proceedings, 3, 1, 579-583.

12. Purich, D.A., Savelyeva, O.S., Tonkonoghii, V.M. (2013). Express-analysis of the structural reliability of complex technical systems with loaded backup. Modern technology in mechanical engineering, 8 , $272-280$.

Тігарєв Володимир Михайлович; Tigarev Volodimir, ORCID: https://orcid.org/0000-0001-8492-6633

Салій Віра Іванівна; Salii Vira, ORCID: https://orcid.org/0000-0003-2426-5241

Лопаков Олексій Сергійович; Lopakov Alexey, ORCID: http:// orcid.org/ 0000-0001-6307-8946

Гончаренко Антон Олексійович; Goncharenko Anton, ORCID: https://orcid.org/0000-0003-4534-9970

Received June 10, 2019

Accepted September 11, 2019 